\title{
The History of Computers and Computing in Virtual Museums
}

\author{
Yuri Polak \\ Chair for Social Informatics, Moscow State University \\ and Russian Academy of Science, Moscow, Russia \\ polak@cemi.rssi.ru
}

\begin{abstract}
Online computer museums have large educational, cultural and aesthetic significance. They promote preservation of our historical and cultural heritage. Edward Proydakov's Virtual Computer Museum launched in 1997 (http://www.computer-museum.ru) is the most representative and professional one in Russia. The unique feature of this project is active participation of outstanding scientists, engineers and designers who created the first Soviet computers. Many of them led projects that later came into legend. Different aspects of this museum's activity are described in the article. Some other Russian projects and foreign virtual museums are also represented.
\end{abstract}

Keywords: Computer, history, virtual museum.

\section{Introduction}

As known, virtual museum is "a collection of digitally recorded images, sound files, text documents, and other data of historical, scientific, or cultural interest that are accessed through electronic media. A virtual museum does not house actual objects and therefore lacks the permanence and unique qualities of a museum in the institutional definition of the term" (Britannica Online). These collections take full advantage of the easy access, loose structure, hyperlinking capacity, interactivity, and multimedia capabilities of the World Wide Web.

Last years a huge quantity of virtual computer museums had appeared in Internet. In early summer 2006 Google returned above 21 million links by inquiry 'Virtual Computer Museum' - naturally, mostly in English, but in other languages as well. Unlike traditional museums, museum in Internet is accessible any time irrespective of time zones, it doesn't demand extensive areas and contains no bulky exhibits. It is especially important for Russia where there are no specialized museums of computer hardware, neither representative collections of mainframes or minicomputers samples. The largest in Russia collection of museum pieces on computer facilities development is available in Polytechnical Museum, Moscow (http://www.polymus.ru). 


\section{The Russian Virtual Computer Museum}

Edward Proydakov's project fills up this gap. His Virtual Computer Museum (http://www.computer-museum.ru) is the most representative and professional one in Russia. This project was launched in 1997, when Proydakov's article 'Let's create a museum' was published in PC Week/Russian Edition \#38, 1997. That time Edward was the Editor-in-Chief of PC Week/RE.

"Once a son of my employee, being the university student of second rate, has asked his mum, if there were any computers before Pentium processor. And I have understood, that the youth simply does not know history of computer facilities"

explains Edward. Soon he got a real support from his colleagues and adherents. The unique feature of this project is active participation of outstanding scientists, engineers and designers who created the first Soviet computers. Now they form the Museum's Advisory board. Despite of very respectable age and health problems, they take part in monthly sessions, write and discuss memoirs and textbooks.

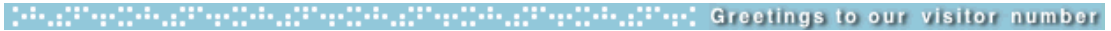

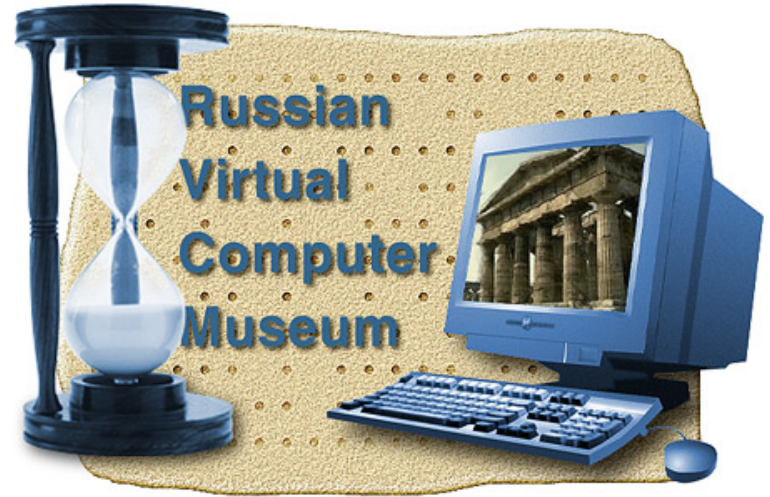

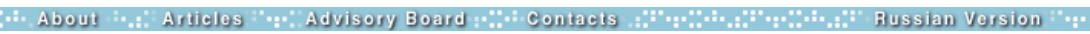

\section{Started by Eduard Proydakov in 1997 \\ Our Sponsors \\ [News] [About] [Articles] [Advisory board] [Contacts] [Russian version] \\ (C) Russian Virtual Computer Museum, 1997-2006.}

Fig. 1. Virtual Computer Museum Home Page (2006) http://www.computer-museum.ru/english/

It is necessary to mention here Prof. Victor Przhiyalkovsky - a Chairman of Museum Council, USSR State premium laureate, Hero of Socialist Labour, the general constructor of ES computer series and other mainframes. Other members of the Advisory board are famous computer designers as well: Prof. Yaroslav 
Khetagurov (special onboard computers for fleet and aircraft); Prof. Alexander Tomilin (BESM-6); Dr. Nikolai Brousentsov ('Setun' - the first and unique in the world computer with figurative symmetric system of numbers representation); Dr. Yuri Rogachov (M-1, M-4, M-10, M-13). Edward Proydakov is a Director of Museum.

Here are the words from Museum's welcome message: "We were driven by the intention to keep public the most unique documents portraying the 50 years of Russian computing, its success and withering. The materials we present, being kept secret for decades, are even now at times being obscured by those unwilling to remember the true history... The members of our Advisory board are well known for their achievements in computer science and electronics, many of them led projects that later came into legend. Our collection includes unique materials on the development of military, special-purpose and universal computers, systems and application software".

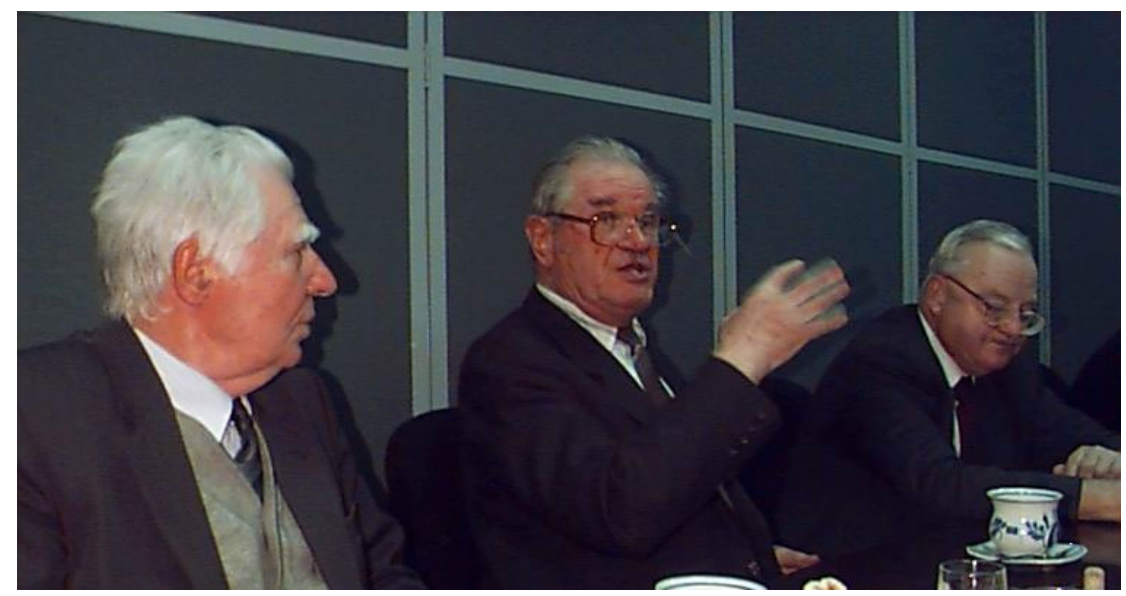

Fig. 2. A session of Advisory board. From left to right: Yuri Rogachov, Victor Przhiyalkovsky, Alexander Tomilin.

The memoirs and scientific biographies of 'pioneers', materials on histories of domestic computer facilities, specifications of many computers are placed on the museum site. This information is supplemented with English-Russian computer dictionary (by E.Proydakov and L.Teplitsky), one of the most authoritative in the country (11000+ terms). Other popular sections of a virtual museum are 'Calendar of events', 'Hall of Fame', 'Documents and publications', 'Calculations in pre-computer age', 'History of domestic computer facilities', 'History of computer facilities abroad', 'History of software development', 'Technology', 'Computer games', 'Books and press'.

The activity of Museum is not limited to supporting a site, it often 'goes to offline'. Joint actions with the Polytechnical Museum took place. Members of Advisory board took part in exhibitions Softool at the All-Russia Exhibition Centre. The textbook on history of domestic computer facilities was prepared for edition. 
In 2006 representative international conference was held in Petrozavodsk under IFIP. Virtual Computer Museum was one of the basic organizers of conference, and the Museum Council formed its Program Committee.

\section{Other Russian Projects}

Academician Ershov's Archive for the History of Computing ${ }^{1}$ is a project of the A.P. Ershov Institute of Informatics Systems of Siberian Branch of Russian Academy of Science (Novosibirsk). Andrei Ershov (1931-1988) has left a unique archive of approximately 500 thick office folders storing documents which reflect his scientific career and simultaneously the history of computer science in Russia and worldwide. After this project was started in 2000, a lot of materials were digitalized, and now archive contains about 35000 documents, 120000+ images and about 6000 persons described. It is a colossal collection of digitized documents connected with scientific, administrative, pedagogical work and daily activity of an outstanding Soviet researcher.

Some organizations - computer developers have created 'corporative museums', web-pages with descriptions the history of their development. So, the Lebedev Institute of Precise Mechanics and Computer Engineering describes BECM, M-20, M-220, BECM-4, BECM-6, Elborus and other computers created in IPMCE. Russian version $^{2}$ is more detailed and illustrated.

The Virtual Museum of informatics ${ }^{3}$ was created and supported by teachers and pupils of a school \#444, one of the best physical and mathematical secondary schools in Moscow. Part of information is borrowed in E. Proydakov's museum. Most of other Russian virtual computer museums have poor original information. Some of them were launched by grant support and now have no renewal. The Museum of Soviet Computers history was created by Associate Professor S.Tarkhov from Ufa with grant support from Soros Foundation in 1999. It contains descriptions of computers, their characteristics, pictures and photos. However this project is not developed now. The 'Unofficial museum of computers in USSR' (Denis Yakimov from Yaroslavl) has the similar destiny. A project 'Virtual museum of computer technologies' was initially a mean for distance learning in the chair 'Projecting and Technology of Computing and Telecommunication Systems' of Bauman State Technical University. Its page ${ }^{5}$ contained many computer descriptions and historical articles from special magazines, but it is not supported now.

Sergey Frolov's original project on Soviet Calculators History started in 1998. Now author has 145 models of Soviet calculators in his collection. 50 more models form a list of items that the author continues to search for. His sites are rich of good pictures and detailed descriptions.

\footnotetext{
See http://ershov.iis.nsk.su/english

See http://www.ipmce.ru/about/history

See http://schools.keldysh.ru/sch444/museum

See http://old.h1.ru

See http://museum.iu4.bmstu.ru/project.shtml
} 


\section{Russian Computers Abroad}

One more virtual 'Museum of Soviet Calculators' was created by Andrew Davie, a collector of hand-held computing devices such as slide rules and electronic calculators. His project isn't so representative as previous one, but the author is excused because he lives too far from Russia, on Tasmania island. By the way, Sergei Frolov has provided most of the images on this site. Its address is: http://www.taswegian.com/MOSCOW/soviet.html, where Moscow means Museum of

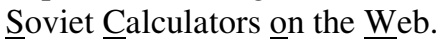

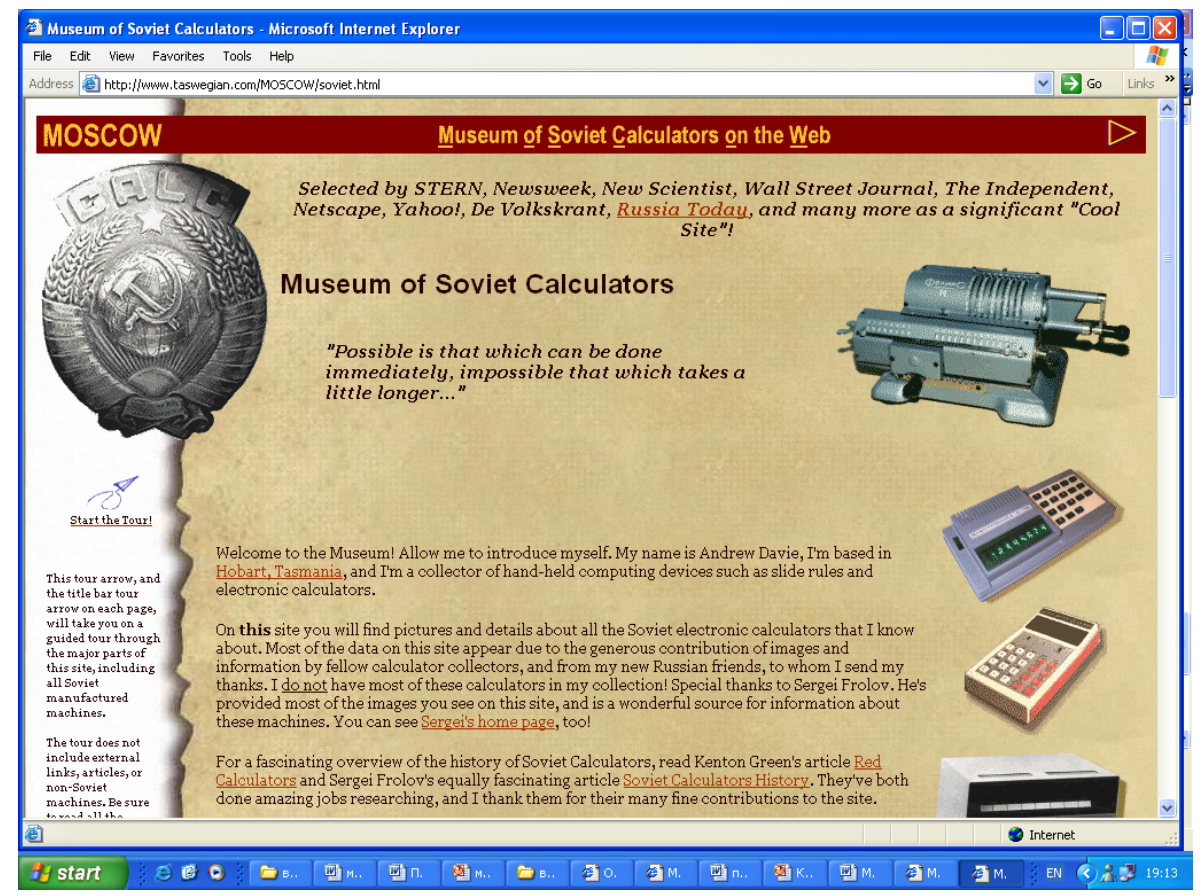

Fig. 3. A screenshot of Tasmanian 'Museum of Soviet Calculators'

Former Soviet citizens often put into Web their reminiscences about hardware and software they dealt with. For example, Leonid A. Broukhis (now citizen of UK) presents his 'BESM-6 Nostalgia Page' (1997-2005). This page is supposed to hold all sorts of information about great Soviet mainframe computer BESM-6. Address: http://www.mailcom.com/besm6.

The information on personal computer 'Agat', a Soviet-made analog of 'Apple-2' can be found among 950 computer descriptions of 'Old-Computers.com', a project of Thierry Schembri and Olivier Boisseau. These two French men met in a pub in London in 1973. 25 years later they decided to launch this project (now hosted by NYI - New York Internet). Computer descriptions are available by name, by company or by year.

6 See http://www.old-computers.com/museum/computer.asp?st=1\&c=509 


\section{Computer Museums in Different Countries}

Foreign virtual museums (abroad) could be divided into two main groups: a) network representations of real (off-line) museums; b) 'pure' virtual collections exclusively accessible via the Internet. The first group is headed by Computer History Museum ${ }^{7}$, the world's largest and most significant history museum for preserving and presenting the computing revolution and its impact on the human experience. Established in 1996, the Computer History Museum is a public benefit organization dedicated to the preservation and celebration of computing history. It is home to one of the largest collections of computing artifacts in the world, a collection comprising over 13,000 objects, 20,000 images, 5,000 moving images, 4,000 linear feet of cataloged documentation and 5,000 titles or several hundred gigabytes of software. In 2005 Bill \& Melinda Gates Foundation had pledged a \$15 million gift to the Computer History Museum. This museum is located on 7.5 acres of land in Mountain View, the heart of Silicon Valley; its new home is a two-story, 119,000 square foot architecturally distinctive structure, designed and developed in 1994.

Computer museums in other countries are mainly parts of more common collections of artifacts and stories of the Scientific Age. Deutsches Museum in München ${ }^{8}$ has a computer exhibition on the 3rd floor which presents some 700 objects on an area of 1020 sq.m. The site has German and English versions. London Science Museum' has a section 'Computing and Information Technology' which covers the devices, machines and systems from 1623 (first mechanical calculator) to the present. Its scope includes electromechanical and electronic calculation, analog and digital computation, data management and processing, and cryptography. Science and Technique, a very large modern museum in Parque La Vilette (Paris, France) has now a special section on informatics on the second floor - 'Musee d'Histoire Informatique ${ }^{10}$. Computermuseum in Netherlands ${ }^{11}$ is open to the public every third Sunday afternoon. Visitors can see 25 mainframe computers, 10 minicomputers, 250 microcomputers and 500+ kinds of Software.

Among corporate museums we'll mention the Intel Museum ${ }^{12}$, very professional and rich of information. This museum is located in Santa Clara (California) and is open to the public 6 days a week without any admission price. The Intel Museum collects, preserves and exhibits Intel corporate history for the purpose of increasing employee, customer and public awareness of Intel innovations, technologies and branding in an interactive and educational manner.

One more Project, the History of Computing Project ${ }^{13}$ is incorporated as a nonprofit organization: History of Computing Foundation. It began in 1986 when somebody asked the original author (Cornelis Robat) during a course he gave: 'Where do computers come from and who started with it'. As we remember, the similar

7 See http://www.computerhistory.org

8 See http://www.deutsches-museum.de

9 See http://www.sciencemuseum.org.uk

${ }^{10}$ See http://mo5.com

${ }^{11}$ See http://www.computermuseum.nl

12 See http://www.intel.com/museum

13 See http://www.thocp.net 
question gave birth to Edward Proydakov's museum. This site contains a large list of hardware and its inventors; rich history of software and computer languages, a collection of historical papers by Pascal, Descartes, Turing, Shannon, Dijkstra and other ancient and modern authors. There are hundreds names in 'Biographies Pioneers of computing'. It also contains a good guide on other museums and even a collection of postage stamps with portraits of Babbage, Bernoulli, Ramanujan, Chebyshev etc.

Founded in 1995, the Virtual Museum of Computing includes an eclectic collection of web-links connected with the history of computing and online computer-based exhibits available both locally and around the world.

The Italian Computer Museum by Massimiliano Fabrizi contains mostly descriptions and characteristics of PCs from 1974 until the late 1980s as well as Polish site Historia Komputera.

The exposition of Ukrainian 'European Virtual Computer Museum'14 mainly follows L. Malinovsky's books The History of Computers in Faces, Essays on Computer Science and Technology in Ukraine and The Known and the Unknown in the History of Computer Technology in Ukraine. Some sections such as The Computer History Abroad are fulfilled in cooperation with E. Proydakov's museum. We shall finish this list of the exotic countries with a mention about Mexican PC Museo and the Latvian Core Memory Museum ${ }^{15}$.

\section{Museums of the Internet}

Internet became now not only environment and mean of information dissemination, but also an object of museum collecting. Let's specify some sources in Russia. Kurchatov Institute for Nuclear Research and Foundation for Internet Development recently introduced their project Museum of Internet History, which simulates a structure of real museum with exhibition halls (not all from them contain information now). Newest history of internet is represented by a research project called The History of the Internet in Russia ${ }^{16}$, which purpose is gathering and analyzing information on development the Internet-technologies in Russia. It presents a chronology since 1990. The old versions of popular Russian and foreign sites are represented in 'Internet-Museum, 17 , where you can go back to the past and imagine the internet as it was in the beginning.

Virtual computer museums promote increase of a general educational and cultural level and computer literacy; to preservation of our historical and cultural heritage.

\footnotetext{
${ }^{14}$ See http://www.icfcst.kiev.ua/museum/museum.html

${ }^{15}$ See http://www.thecorememory.com

16 See http://www.nethistory.ru

17 See http://museum.uka.ru
} 